\title{
165. 平板型放電ランプの検討
}

\author{
品田眞一生田靖 広瀨克弘十志賀智-十五十嵐清†御子柴茂生十 \\ （株式会社日立製作所）（†電気通信大学 電子工学科）
}

1.はじめに

液昆ディスプレイの用途は広範四に渡り、久くことのできない表示デバイスになって いる。このため、表示用バックライトは極めて重要な要素で、その性能に対する要求は より-.層澱しい。バックライト用として、外部電極型の平板型放電ランプ[1]と、その 駆動方法〔2〕を考案し検討してきたが、この 闻者老組合せた結果について報告する。

\section{2. 放電ランプの構造}

図1 に平板型放電ランプの構造を示す。前 面ガラス基板には一刘の放電電極が設けられ、 その表面を誘電体で覆ってある。背面ガラス 基板には监光体が叙布されており、内部には $\| \mathrm{g}-\mathrm{Ar}$ が封入されている。

\section{3. 駆動 方法}

駆動波形を図 2 に示す。負の矩形電圧パル ス老基本とし、回路とランプの開にコイルを 㧴入した。コイルを入れると、パルスの立上 がり、立ち下がりにリンギングが発生し、基 本パルスに高周波パルスが重畳された波形と なる。この電压パルスを各電極に互いに坐周 期ずらして印加し、放電させる。

\section{4. 結果と検討}

図3にコイル付き駆動方法と、コイルなし 駆動方法（通常駆動）で放電させた平板型放 電ランプの輝度と周波数の関係を示す。基本 パルスの幅は $1 \mu \mathrm{s}$ で、電圧は $600 \mathrm{~V}$ 一定 の条俳である。

コイル付き駆動も、通常駆動も周波数を高 くするに従い輝度も高くなるが、コイル付き 駆動は通常駆動に比へ、、約 $20 \%$ の輝度向上 が図れた。コイル付き駆動の場合、リンギン グによる電圧の增加があるが、これを考虑し ても高辉度が得られている。放電管の実験で、 コイル付き駆動では、負グローが減少し高効 率になったが、平板型放電ランプにおいても 间椂ひ結果が得られた。コイル付き駆動方法 を朋いれば、高輝度、高効率なバックライ

卜用平板型ランプ実現の可能性がある。

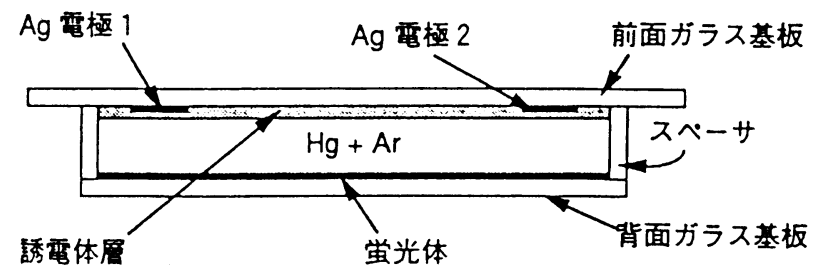

図 1 放電ランプの構造

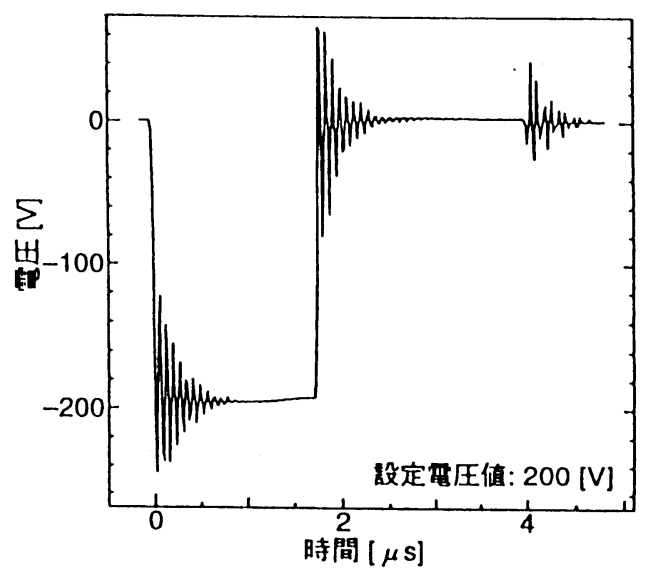

図 2 駆動 波 形

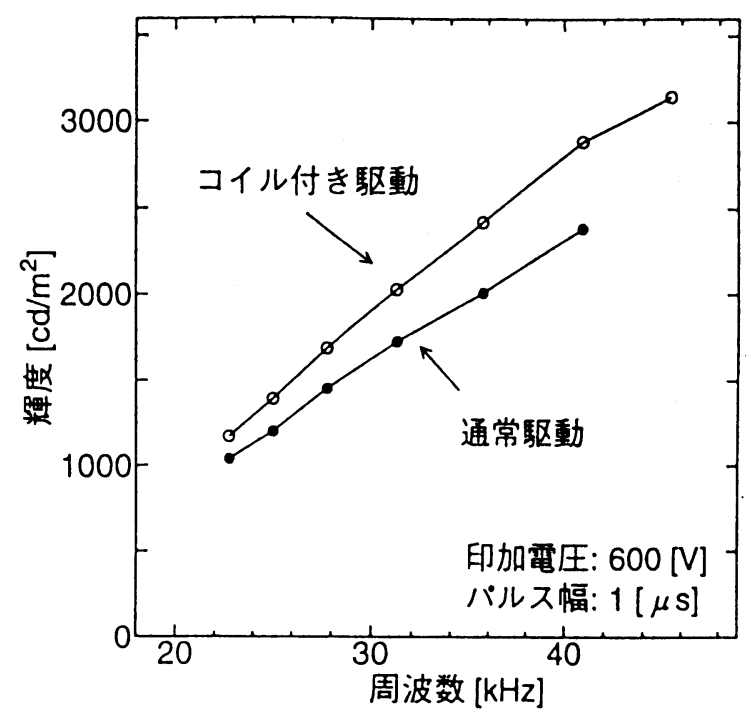

図 3 輝度と周波数の関係

参考文献 [1]広瀬 他：外部電極を用いた液晶バックライト用…：TV 学技術報告 Vol. 19 No.66（1995-11）

[2]志賀 他：駆動電圧パルスの選択による外部電極…：照学研究会資料 LS-95-7 p. 1 (1995-6)

Flat Fluorescent Discharge Lamp with External Electrodes

Shinichi Shinada, Yasushi Ikuta, Katuhiro Hirose, Tomokazu Shiga. Kiyoshi Igarashi, Shigeo Mikoshiba 